Available online at: http://ejournal-balitbang.kkp.go.id/index.php/iaj

\title{
METABOLIC RATES (SMR, RMR, AMR, AND MMR) OF Oplegnathus fasciatus ON DIFFERENT TEMPERATURE AND SALINITY SETTINGS
}

\author{
Vitas Atmadi Prakoso*)* and Young Jin Chang*) \\ *) Institute for Freshwater Aquaculture Research and Fisheries Extension \\ * Institute of Review and Assessment on Fishery and Aquaculture, South Korea
}

(Received 30 May 2017; Final revised 11 September 2017; Accepted 13 September 2017)

\begin{abstract}
The metabolic rate of aquatic animals is closely related to oxygen concentration and influenced by internal and external factors. Despite its high value as marine fish species in South Korea, information on rock bream Oplegnathus fasciatus metabolism is scarcely available. This study observed the standard metabolic rate (SM R), routine metabolic rate (RM R), and active metabolic rate (AMR) of rock bream Oplegnathus fasciatus subjected to different temperature settings. Another observation was performed to find out the maximum metabolic rate (MMR) on rock bream subjected to different salinity settings. Fish (TL: $26.86 \pm 0.29 \mathrm{~cm}$ and BW: $469.40 \pm 38.21 \mathrm{~g}$ for SMR, RMR, and AMR measurement; TL: $26.7 \pm 0.4 \mathrm{~cm}$ and BW: $451.0 \pm 44.4 \mathrm{~g}$ for MMR measurement) were observed using respirometer (dimension $=30 \mathrm{~cm} \times 20 \mathrm{~cm} \times 20 \mathrm{~cm}$; volume: $10.4 \mathrm{~L}$ ) inside a recirculation systems. SMR, RMR, and AMR were measured at $15^{\circ} \mathrm{C}, 20^{\circ} \mathrm{C}$, and $25^{\circ} \mathrm{C}$. Meanwhile, MMR was measured at 15,25 , and 35 psu. The results showed that SMR, RMR, and AMR increased linearly by increasing the temperatures (SMR: $58.7 \pm 3.2,102.7 \pm 4.3$, and $157.1 \pm 4.1 \mathrm{mg} \mathrm{O}_{2} / \mathrm{kg} / \mathrm{h}$ at $15^{\circ} \mathrm{C}, 20^{\circ} \mathrm{C}$, and $25^{\circ} \mathrm{C}$, respectively; RMR: $66.0 \pm 8.6,112.6 \pm 10.2$, and $175.2 \pm 21.3 \mathrm{mg} \mathrm{O} / 2 / \mathrm{kg} / \mathrm{h}$ at $15^{\circ} \mathrm{C}, 20^{\circ} \mathrm{C}$, and $25^{\circ} \mathrm{C}$, respectively; AMR: $73.4 \pm 7.4,122.0 \pm 6.3$, and $196.7 \pm 15.4 \mathrm{mg} \mathrm{O}_{2} / \mathrm{kg} / \mathrm{h}$ at $15^{\circ} \mathrm{C}, 20^{\circ} \mathrm{C}$, and $25^{\circ} \mathrm{C}$, respectively), whilst MMR decreased by lowering salinity $\left(48.5 \pm 5.2,61.1 \pm 5.5\right.$, and $89.3 \pm 14.7 \mathrm{mg} \mathrm{O} \mathrm{O}_{2} l$ $\mathrm{kg} / \mathrm{hour}$ at salinity of 15,25 , and $35 \mathrm{psu}$, respectively).
\end{abstract}

\section{KEYWORDS: rock bream; Oplegnathus fasciatus; temperature; salinity; metabolic rates}

\section{INTRODUCTION}

Oxygen is one of the limiting factors in aquaculture. Its effect is associated with fish metabolism which is currently regarded as one of the most studied physiological characteristics in animals (White et al., 2013). In addition, there are other variables affecting metabolism (Chabot et al., 2016; Rosewarne et al., 2016). Previous researches had been conducted to observe the effects of external factors on the metabolic rate of fish, such as temperature (Requena et al., 1997; Gillooly et al., 2001; Sarma et al., 2010), salinity (Iwama et al., 1997; Jeong et al., 2007; Prakoso et al., 2016), and stocking density (Bjornsson \& Olafsdottir, 2006). Temperature and salinity have strong relationships with dissolved oxygen related to fish physiological response which could result in

\footnotetext{
\# Correspondence: Institute for Freshwater Aquaculture Research and Fisheries Extension. Jl. Sempur No.1, Bogor 16129, West Java, Indonesia.

Phone: + 622518313200

E-mail: vitas.atmadi@gmail.com
}

metabolic stress if the condition is not suitable (Mamun et al., 2013; Prakoso et al., 2015).

Rock bream Oplegnathus fasciatus is one of the important aquaculture species highly priced in South Korea. The fry of this species is cultured in hatcheries and released into the sea to maintain its sustainable stocks (Kim et al., 2008; Lipton \& Kim, 2009). The geographic distribution of rock bream is within the region of Korea, Japan, Taiwan, and Hawaii in the North West and Eastern Central Pacific (Froese \& Pauly, 2017).

Several types of metabolic rate are measured in previous studies such as standard metabolic rate (Halsey et al., 2015; Mamun et al., 2013), routine metabolic rate (Oh et al., 2006; Prakoso et al., 2015; 2016), active metabolic rate (Ohlberger et al., 2007; Mamun et al., 2013), and maximum metabolic rate (Norin \& Clark, 2016; Killen et al., 2016). First, in his journal, J.R. Brett defined that "the standard metabolic rate is the minimum energy required for the fish to survive, associated with rest and unfed state" (Brett, 
1964). Second, F.E.J Fry noted in his journal that "the routine metabolic rate is the fraction of energy used by unfed fish with movement of spontaneous swimming or routine activity" (Fry, 1971). Third, the active metabolic rate is defined by T. Norin and $\mathrm{H}$. Malte as "the metabolic rate during high level of activity at a given temperature, provides the upper boundary for aerobic energy metabolism" (Norin \& Malte, 2011). Fourth, the maximum metabolic rate is described by T. Norin and T.D. Clark in their journal as "the maximum rate of oxygen consumption that a fish can achieve at a given temperature under any ecologically relevant circumstance" (Norin \& Clark, 2016). However, the previous study on metabolic rates is still confined to other species. The limited knowledge on metabolic rates of rock bream is only available from a few study such as Oh et al. (2006); Yan et al. (2008); Ao (2015); and Prakoso et al. (2016). The information about metabolic rates could be applied to the fish aquaculture management. Therefore, in this study, we investigated standard metabolic rate $(S M R)$, routine metabolic rate (RMR), active metabolic rate (AMR), and maximum metabolic rate (MMR) of individually reared rock bream subjected to different rearing temperature and salinity settings.

\section{MATERIALS AND METHODS}

The study was conducted at the Laboratory of Fish Reproductive and Physiology at Pukyong National University, Busan, South Korea. The observation of metabolic rates on rock bream treated with different temperatures had been conducted in previous studies by Oh et al. (2006) and Ao (2015). However, these studies only measure the routine metabolic rate of fish. Furthermore, observation of fish metabolic rates in different salinity levels had also been conducted in other studies by Yan et al. (2008) and Ao (2015). However, both studies did not measure MMR. Based on those previous studies, this study aimed to obtain the information that has not been observed before. Rock bream (the total length: $26.86 \pm 0.29 \mathrm{~cm}$ and total weight of $469.40 \pm 38.21 \mathrm{~g}$ for SMR, RMR, and AMR measurement; the total length: $26.7 \pm 0.4 \mathrm{~cm}$ and total weight: $451.0 \pm 44.4 \mathrm{~g}$ for MMR measurement) were maintained within indoor recirculation system prior to the experiment. The fish were fed $2 \%$ of their body weight using commercial feed. The feed was given in the morning and evening (twice per day). One day before the experiment, fish were starved for 24 hours to avoid the influence of the feed to their metabolism. All experimental conditions in this study were described in Table 1.
Measurements using respirometer (dimensions: $30 \mathrm{~cm} \times 20 \mathrm{~cm} \times 20 \mathrm{~cm}$; volume: $10.4 \mathrm{~L}$ ) were conducted following the methods suggested by Chang et al. (2005). The data from the experiments were used to calculate the metabolic rates and $Q_{10}$ (the coefficient of factor where the reaction rate increases when the temperature is raised by 10 degrees). The coefficient $Q_{10}$ represents the degree of muscle dependence on the temperature measured by the level of contraction. If the reaction rate is completely independent to temperature, then the resulting $Q_{10}$ value is 1.0. It indicates muscle dependence to temperature. If the reaction rate increases with increasing temperature, the value of $Q_{10}$ will be greater than 1.0. An increase of $Q_{10}$ value indicates an increase in temperature dependence. Meanwhile, a value of $Q_{10}$ of less than 1.0 indicates negative temperature dependence, i.e. a decrease in muscle performance along with rising temperatures (Bennett, 1984). SMR, RMR, and AMR were taken as the lowest, average, and the highest oxygen consumption sustained for at least 1.5 hours by fish that had been undisturbed and unfed within 24 hours of observation (Fry, 1957; Beamish, 1964; Becker \& Fishelson, 1990; Focken et al., 1994). Meanwhile, calculations and measurements of MMR performed in this study were adopted from the method conducted by Cutts et al. (2002). The maximum metabolic rate was measured by chasing the fish using a large scope net in the rearing tank for two minutes. After the fish exhausted, they were quickly inserted into the respirometer. During the measurement, a quick check was performed to make no air bubbles existed inside the respirometer. Measurements were performed for 15 times in each replication of MMR measurement to obtain the estimated MMR. During the experiment, photoperiod was set on the condition of $12 \mathrm{~L}: 12 \mathrm{D}$.

In this study, $Q_{10}$ values were calculated using the formula:

$$
Q_{10}=\left(\frac{R_{2}}{R_{1}}\right)^{\left(\frac{10}{t_{2}-t_{1}}\right)}
$$

Where $\mathrm{R}_{1}=$ metabolic rate at $\mathrm{t}_{1}$ temperature, and $R_{2}=$ metabolic rate at $t_{2}$ temperature. For temperature treatments, $Q_{10}$ values were collected by rearing the fish at 32 psu with different temperature settings $\left(15^{\circ} \mathrm{C}, 20^{\circ} \mathrm{C}\right.$, and $\left.25^{\circ} \mathrm{C}\right)$. Meanwhile, for salinity treatments, $Q_{10}$ values were collected by rearing the fish at three different salinity levels $(15,25$, and 35 psu) with different temperatures $\left(15^{\circ} \mathrm{C}, 20^{\circ} \mathrm{C}\right.$, and 
Table 1. Experimental conditions during observation of metabolic rates on rock bream Oplegnathus fasciatus

\begin{tabular}{cccccc}
\hline Experiment & $\begin{array}{c}\text { Salinity } \\
\text { (psu) }\end{array}$ & $\begin{array}{c}\text { Water } \\
\text { temperature }\left({ }^{\circ} \mathbf{C}\right)\end{array}$ & $\begin{array}{c}\text { Fish number } \\
\text { (individu) }\end{array}$ & Replication \\
\hline Measuring SMR, RMR, & 1 & 32 & 15 & 1 & 3 \\
and AMR & 2 & 32 & 20 & 1 & 3 \\
& 3 & 32 & 25 & 1 & 3 \\
\hline \multirow{3}{*}{ Measuring MMR } & 1 & 35 & 15 & 1 & 3 \\
& 2 & 25 & 15 & 1 & 3 \\
& 3 & 15 & 15 & 1 & 3 \\
\hline
\end{tabular}

Description: $S M R=$ standard metabolic rate, $R M R=$ routine metabolic rate, $A M R=$ active metabolic rate, $M M R=$ maximum metabolic rate

$25^{\circ} \mathrm{C}$ ). Data were analyzed by one-way ANOVA using statistical software PASW Statistics 18.

\section{RESULTS AND DISCUSSION}

Temperature affects all biochemical reactions in the body and has a significant impact on the physiology of the organism. Therefore, research on the tolerance to temperature and its effect on fish health is important to be observed. As shown in Table 2, the values of $S M R, R M R$, and AMR showed significant difference based on three different temperature levels $(P<0.05)$. The SMR values increased significantly with the increase in temperature $(58.7 \pm 3.2,102.7$ \pm 4.3 , and $157.1 \pm 4.1 \mathrm{mg} 02 / \mathrm{kg} / \mathrm{h}$ at $15^{\circ} \mathrm{C}, 20^{\circ} \mathrm{C}$, and $25^{\circ} \mathrm{C}$, respectively), whilst the lowest values of RMR and AMR of rock bream were found at $15^{\circ} \mathrm{C}(66.0$ \pm 8.6 and $73.4 \pm 7.4 \mathrm{mg} 0_{2} / \mathrm{kg} / \mathrm{h}$, respectively) compared with the value of RMR and AMR observed at $20^{\circ} \mathrm{C}\left(112.6 \pm 10.2\right.$ and $122.0 \pm 6.3 \mathrm{mg} 0_{2} / \mathrm{kg} / \mathrm{h}$, respectively) and $25^{\circ} \mathrm{C}(175.2 \pm 21.3$ and $196.7 \pm 15.4$ $\mathrm{mg} \mathrm{O}_{2} / \mathrm{kg} / \mathrm{h}$, respectively).

The process of metabolism in fish usually has a positive correlation with temperature. This is due to the Van't Hoff effect, where the rate of biochemi- cal reactions increases exponentially with temperature (Marshall \& McQuaid, 2011; Branch \& Newell, 1978). Higher temperatures increase the proportion of enzymes that have reached their activation energy levels, which accelerate the average rate of biochemical reactions to allow for more activity (Houlihan \& Innes, 1984) and require more oxygen (Bartholomew $\&$ Casey, 1977). Therefore, the metabolic rate of an ectothermic animal is closely related to temperature, because the temperature regulates routine metabolic rate (RMR) and indirectly triggers active metabolic rate (AMR).

In this study, the metabolic rates of rock bream were affected by temperature increase. These results are consistent with the studies using different fish species which reported that the oxygen demand of the fish increased linearly with temperature increase (Gardner \& King, 1922; Chang et al., 2005; Oh et al., 2006). Both behavioral and physiological factors can influence how temperature affects the activity level and metabolic rate of ectothermic animals. From the perspective of behavior, for example, at a temperature where the chance is high to get food, animals can increase their activity level to maximize energy

Table 2. Metabolic rates of rock bream Oplegnathus fasciatus measured at different temperatures

\begin{tabular}{|c|c|c|c|}
\hline \multirow{2}{*}{\multicolumn{2}{|c|}{$\begin{array}{l}\text { Temperature } \\
\left({ }^{\circ} \mathrm{C}\right)\end{array}$}} & \multicolumn{2}{|c|}{ Metabolic rate $\left(\mathrm{mg} \mathrm{O}_{2} / \mathrm{kg} / \mathrm{h}\right)$} \\
\hline & & RMR & AMR \\
\hline & & $66.0 \pm 8.6^{c}$ & $73.4 \pm 7.4^{c}$ \\
\hline & & $112.6 \pm 10.2^{b}$ & $122.0 \pm 6.3^{b}$ \\
\hline & 25 & $175.2 \pm 21.3^{\mathrm{a}}$ & $196.7 \pm 15.4^{\mathrm{a}}$ \\
\hline
\end{tabular}


intake (Speakman, 1986). Alternatively, they may be less active due to, for example, there are many predators (Anholt et al., 2000; Werner \& Anholt, 1993). In terms of the physiological perspective, there is a direct effect of temperature on biochemical reactions involved in the movement (Halsey et al., 2015).

As shown in Table 3, salinity changes have a significant impact on fish metabolism. In this study, the mean values of MMR in rock bream were $48.5 \pm 5.2$, $61.1 \pm 5.5$, and $89.3 \pm 14.7 \mathrm{mg} \mathrm{O}_{2} / \mathrm{kg} / \mathrm{h}$, respectively on 15,25 , and 35 psu. The values showed significant differences based on salinity treatment $(P<0.05)$.

MMR of rock bream in each treatment showed significant differences related to different salinity settings $(P<0.05)$. The results showed the tendency of MMR in rock bream decreasing in line with lowering salinity level. The lowest value of MMR was found at 15 psu. MMR of rock bream at 25 and 15 psu each was $54.3 \%$ and $68.4 \%$ lower than MMR at 35 psu. This phenomenon is in accordance with the opinion of Morgan \& Iwama (1991) who argued that salinity is closely related to low metabolic rate. In this study, the results show that in the low-salinity environment, the activity level of rock bream had lowered. The results of this study were also similar to the findings of Jeong et al. (2007) observing Acanthopagrus schelgelii and Prakoso et al. (2015) studying Mugil cephalus. These studies found that the metabolic rates of fish reared in freshwater were lower than those of seawater. The declining of MMR is due to the effect of reduced gill permeability to prevent water intrusion and ion loss in gill epithelium. A similar effect of salinity change on MMR also applies to freshwater fish. The reduction in gill permeability will occur to reduce osmotic stress (Gonzalez \& McDonald, 1992). This indicates an interaction between salinity and aerobic performance of rock bream.

The $Q_{10}$ value for $S M R$ between $15^{\circ} \mathrm{C}$ and $20^{\circ} \mathrm{C}$ (3.1) was higher than those of $S M R$ at $20^{\circ} \mathrm{C}-25^{\circ} \mathrm{C}(2.3)$. The
$\mathrm{Q}_{10}$ value calculated from $\mathrm{RMR}$ at $15^{\circ} \mathrm{C}-20^{\circ} \mathrm{C}$ was higher (2.9) than those calculated from RMR at $20^{\circ} \mathrm{C}-25^{\circ} \mathrm{C}$ (2.4) and $15^{\circ} \mathrm{C}-25^{\circ} \mathrm{C}(2.7)$. Meanwhile, the $Q_{10}$ value calculated from AMR at $20^{\circ} \mathrm{C}-25^{\circ} \mathrm{C}$ was higher (3.1) compared with the values calculated from $A M R$ at $15-$ $20^{\circ} \mathrm{C}(2.7)$ and $15^{\circ} \mathrm{C}-25^{\circ} \mathrm{C}(2.7)$. The lowest $Q_{10}$ values were found from the calculation of SMR and RMR values at $20^{\circ} \mathrm{C}-25^{\circ} \mathrm{C}$ ( 2.3 and 2.4 , respectively) (Table 4). Moreover, based on different salinity settings, the highest average $Q_{10}$ was found in the temperature range of $15^{\circ} \mathrm{C}-20^{\circ} \mathrm{C}$ at salinity of $15 \mathrm{psu}$, with a value of 10.2 , while the lowest average value of $Q_{10}$ was obtained in the temperature setting of $20^{\circ} \mathrm{C}-25^{\circ} \mathrm{C}$ at salinity of 15 psu with a value of 2.5 (Table 5 ).

A similar increase in SMR with the increase in temperature was also observed in this study. The effect of temperature on SMR was evident by looking at the increase of $Q_{10}$ values when temperature was increased from $15^{\circ} \mathrm{C}$ to $20^{\circ} \mathrm{C}\left(Q_{10}=3.1\right)$ than $20^{\circ} \mathrm{C}$ to $25^{\circ} \mathrm{C}\left(\mathrm{Q}_{10}=2.3\right)$ and $15^{\circ} \mathrm{C}$ to $25^{\circ} \mathrm{C}\left(\mathrm{Q}_{10}=2.7\right)$. $\mathrm{A}$ similar effect of temperature on SMR was also observed in goldfish (Beamish \& Mookherjii, 1964) and black porgy (Jeong et al., 2007). Temperature has a significant effect on the speed and strength of muscle contraction of living things. In general, muscle performance decreases with decreased temperature and increases with increasing temperature.

In most biological processes, especially those involving large-scale protein conformation changes, the value of $Q_{10}$ is greater than two, or in the range of 2 to 3 (Reyes et al., 2008). A decrease in temperature in muscle causes a significant decrease in muscle performance in which a $10^{\circ} \mathrm{C}$ temperature drop resulting in at least $50 \%$ reduction in muscle performance (Deban \& Lappin, 2011). In vertebrates, different muscle activities have different dependences on temperature. The degree of muscle contraction and relaxation depends on temperature $\left(Q_{10}=2.0-2.5\right)$, whereas the maximum contraction is independent of

Table 3. Average value of maximum metabolic rate on rock bream Oplegnathus fasciatus treated in different salinity levels at $15^{\circ} \mathrm{C}$ rearing temperature

\begin{tabular}{cc}
\hline Salinity (psu) & MMR (mg 0 $\mathbf{2} / \mathbf{k g} / \mathbf{h})$ \\
\hline 15 & $48.5 \pm 5.2^{\mathrm{c}}$ \\
25 & $61.1 \pm 5.5^{\mathrm{b}}$ \\
35 & $89.3 \pm 14.7^{\mathrm{a}}$ \\
\hline
\end{tabular}

Description: $\quad M M R=$ maximum metabolic rate; each values represent means $\pm S D(n=15)$. Different superscript letters in the same column indicate significant differences $(P<0.05)$ 
Table 4. $Q_{10}$ values of different metabolic rates on rock bream Oplegnathus fasciatus measured at $15^{\circ} \mathrm{C}$ to $25^{\circ} \mathrm{C}$

\begin{tabular}{cccc}
\hline \multirow{2}{*}{$\begin{array}{c}\text { Metabolic } \\
\text { rates }\end{array}$} & \multicolumn{3}{c}{ Temperature range $\left({ }^{\circ} \mathrm{C}\right)$} \\
\cline { 2 - 4 } & $\mathbf{1 5 - 2 0}$ & $\mathbf{2 0 - 2 5}$ & $\mathbf{1 5 - 2 5}$ \\
\hline SMR & 3.1 & 2.3 & 2.7 \\
RMR & 2.9 & 2.4 & 2.7 \\
AMR & 2.8 & 3.1 & 2.7 \\
\hline
\end{tabular}

Description: $\quad S M R=$ standard metabolic rate, $R M R=$ routine metabolic rate, $A M R=$ active metabolic rate

Table 5. Average $Q_{10}$ values of rock bream Oplegnathus fasciatus on three different salinity levels measured at $15^{\circ} \mathrm{C}$ to $25^{\circ} \mathrm{C}$

\begin{tabular}{cccc}
\hline \multirow{2}{*}{$\begin{array}{c}\text { Temperature range } \\
\text { ( } \mathbf{C})\end{array}$} & \multicolumn{3}{c}{$\mathbf{Q}_{\text {10 value }}$} \\
\cline { 2 - 4 } & $\mathbf{1 5} \mathbf{~ p s u}$ & $\mathbf{2 5} \mathbf{~ p s u}$ & $\mathbf{3 5}$ psu \\
\hline $15-20$ & 10.2 & 4.5 & 2.6 \\
$20-25$ & 2.5 & 3.4 & 3.0 \\
$15-25$ & 4.8 & 3.9 & 2.7 \\
\hline
\end{tabular}

temperature (Bennett, 1985). Therefore, the value of $\mathrm{Q}_{10}$ can be used to describe the physiological processes of the object under investigation. The results from the present study indicated that temperature variation between $15^{\circ} \mathrm{C}$ and $20^{\circ} \mathrm{C}$ was within suitable range for rock bream to maintain their maximum metabolic efficiency. Furthermore, this study found that salinity rearing at 15 psu on temperature range from $15^{\circ} \mathrm{C}$ to $20^{\circ} \mathrm{C}$ has the highest reaction rate to maintain the metabolism efficiency for rock bream. Hence, important metabolic rates information of rock bream discussed in this paper might provide valuable information for commercial aquaculturists to ensure sustainable aquaculture management practice. Specifically, the scientific knowledge on the metabolic performance of rock bream under different environmental conditions is very important to enhance their growth and survival.

\section{CONCLUSION}

The results showed the tendency of metabolic rates of rock bream Oplegnathus fasciatus increased linearly with the increased in temperature; with the standard metabolic rate (SMR), routine metabolic rate (RMR), and active metabolic rate (AMR) were significantly higher at higher temperatures (SMR: $58.7 \pm$ $3.2,102.7 \pm 4.3$, and $157.1 \pm 4.1 \mathrm{mg} \mathrm{O}_{2} / \mathrm{kg} / \mathrm{h}$ at $15^{\circ} \mathrm{C}$, $20^{\circ} \mathrm{C}$, and $25^{\circ} \mathrm{C}$, respectively; RM R: $66.0^{\circ} \pm 8.6,112.6$ \pm 10.2 , and $175.2 \pm 21.3 \mathrm{mg} \mathrm{O} / \mathrm{kg} / \mathrm{h}$ at $15^{\circ} \mathrm{C}, 20^{\circ} \mathrm{C}$, and $25^{\circ} \mathrm{C}$, respectively; AMR: $73.4 \pm 7.4,122.0 \pm$ 6.3 , and $196.7 \pm 15.4 \mathrm{mg} 0_{2} / \mathrm{kg} / \mathrm{h}$ at $15^{\circ} \mathrm{C}, 20^{\circ} \mathrm{C}$, and $25^{\circ} \mathrm{C}$, respectively).

The value of the maximum metabolic rate (MMR) of rock bream was also decreased with lowered salinity. The results from this present study on $Q_{10}$ values indicated that the range from $15^{\circ} \mathrm{C}$ and $20^{\circ} \mathrm{C}$ was within acceptable value for rock bream to maintain their maximum metabolic efficiency. Meanwhile, the value of $Q_{10}$ indicates that salinity of 15 psu is the highest point on reaction rate to temperature increase for rock bream compared with 25 and 35 psu. Further research is needed to study the lethal dissolved oxygen level for rock bream reared under certain temperature levels.

\section{ACKNOWLEDGEMENTS}

The authors wish to thank Dr. Byung-Hwa Min, Dr. Min-Hwan Jeong, Kitae Kim, and Jun-Hyung Ryu for their contribution to the research. As well as to KOICA and Pukyong National University for the facilities provided during the study.

\section{REFERENCES}

Anholt, B.R., Werner, E., \& Skelly, D.K. (2000). Effect of food and predators on the activity of four larval ranid frogs. Ecology, 81, 3509-3521. 
Ao, V. (2015). Effects of temperature, salinity and fish number on oxygen consumption and blood property of young rockbream Oplegnathus fasciatus. Master Thesis. Koica-PKNU International Graduate Program of Fisheries Science, Graduate School, Pukyong National University, Korea, 86 pp.

Bartholomew, G.A., \& Casey, T. (1977). Endothermy during terrestrial activity in large beetles. Science, 195, 882-883.

Beamish, F.W.H. (1964). Respiration of fishes with special emphasis on standard oxygen consumption. III. Influence of oxygen. Canadian Journal of Zoology, 42, 355-366.

Beamish, F.W.H., \& Mookherjii, P.S. (1964). Respiration of fishes with special emphasis on standard oxygen consumption. II. Influence of weight and temperature on respiration of goldfish, Carassius auratus L. Canadian Journal of Zoology, 42, 161175.

Becker, K., \& Fishelson, L. (1990). M etabolic rate and growth potential of various tilapias. Journal of Applied Ichthyology, 6, 51-58.

Bennett, A.F. (1984). Thermal dependence of muscle function. American Journal of Physiology, 247, 217229.

Bennett, A.F. (1985). Temperature and muscle. Journal of Experimental Biology, 115, 333-344.

Bjornsson, B., \& Olafsdottir, S.R. (2006). Effects of water quality and stocking density on growth performance of juvenile cod (Gadus morhua L.). ICES Journal of Marine Science, 63, 326-334.

Branch, G.M., \& Newell, R.C. (1978). A comparative study of metabolic energy expenditure in the limpets Patella cochlear, P. oculus, and P. granularis. Marine Biology, 49, 351-361.

Brett, J.R. (1964). The respiratory metabolism and swimming performance of young sockeye salmon. Journal of the Fisheries Research Board of Canada, 21, 1183-1226.

Chabot, D., Steffensen, J.F., \& Farrell, A.P. (2016). The determination of standard metabolic rate in fishes. Journal of Fish Biology, 88, 81-121.

Chang, Y.J., Jeong, M.H., Min, B.H., Neill, W.H., \& Fontaine, L.P. (2005). Effect of photoperiod, temperature, and fish size on oxygen consumption in the black porgy Acanthopagrus schlegelii. Journal of Fish Science and Technology, 8, 142-150.

Cutts, C.J., Metcalfe, N.B., \& Taylor, A.C. (2002). Juvenile Atlantic salmon (Salmo salar) with relatively high standard metabolic rates have small metabolic scopes. Functional Ecology, 16, 73-78.

Deban, S.M., \& Lappin, A.K. (2011). Thermal effects on the dynamics and motor control of ballistic prey capture in toads: maintaining high performance at low temperature. The Journal of Experimental Biology, 214, 1333-1346.

Focken, U., Schiller, M., \& Becker, K. (1994). A computer-controlled system for the continuous determination of metabolic rates of fish. In Kestemont, P., Muir, J., Sevilla, F., \& Willot, P. (Eds.). Measures of success, International Conference Bordeaux Aquaculture 1994. CEMAGREF Editions, Antony Cedex, p. 167-171.

Froese, R., \& Pauly, D. (Eds.). (2017). FishBase. [version 04/2017]. http://www.fishbase.org.

Fry, F.E.J. (1957). The aquatic respiration of fish. In Brown, M.E. (Ed.), The Physiology of Fishes, 447 pp. New York, USA: Academic Press Inc., p. 1-63.

Fry, F.E.J. (1971). The effect of environmental factors on the physiology of fish. In Hoar, W.S., \& Randall, D.J. (Eds.). Fish Physiology. New York, USA: Academic Press Inc., 6, 1-98.

Gardner, J.A., \& King, G. (1922). Respiratory exchange in freshwater fish, further comparison of goldfish and trout. Biochemical Journal, 16, 729-735.

Gillooly, J.F., Brown, J.H., West, G.B., Savage, V.M., \& Charnov, E.L. (2001). Effects of size and temperature on metabolic rate. Science, 293, 2248-2251.

Gonzalez, R.J., \& McDonald, D.G. (1992). The relationship between oxygen consumption and ion loss in a freshwater fish. The Journal of Experimental Biology, 163, 317-332.

Halsey, L.G., Matthews, P.G.D., Rezende, E.L., Chauvaud, L., \& Robson, A.A. (2015). The interactions between temperature and activity levels in driving metabolic rate: theory, with empirical validation from contrasting ectotherms. Oecologia, 13 pp.

Houlihan, D., \& Innes, A. (1984). The cost of walking in crabs: aerial and aquatic oxygen consumption during activity of two species of intertidal crab. Comparative Biochemistry and Physiology Part A, 77, 325-334.

Iwama, G.K., Takemura, A., \& Takano, K. (1997). Oxygen consumption rates of tilapia in freshwater, seawater, and hypersaline seawater. Journal of Fish Biology, 51, 886-894.

Jeong, M.H., Kim, Y.S., Min, B.H., \& Chang, Y.J. (2007). Effect of fish number in respiratory chamber on routine oxygen consumption of black porgy Acanthopagrus schlegelii reared in seawater or freshwater. Journal of Aquaculture, 20, 121-126.

Killen, S.S., Glazier, D.S., Rezende, E.L., Clark, T.D., Atkinson, D., Willener, A.S.T., \& Halsey, L.G. (2016). Ecological influences and morphological correlates of resting and maximal metabolic rates across 
teleost fish species. The American Naturalist, 187, 592-606.

Kim, M.J., An, H.S., Hong, S.W., \& Park, J.Y. (2008). Investigation of genetic diversity between wildcaught and hatchery-reared rock bream Oplegnathus fasciatus using microsatellite DNA analysis. Journal of the Fisheries Science and Technology, 11(2), 82-87.

Lipton, D.W., \& Kim, D.H. (2009). Accounting for economic risk and uncertainty in offshore aquaculture: A case study of Korean rock bream production. Bulletin of National Fisheries Research and Development Agency, 29, 93-102.

Mamun, S.M., Focken, U., \& Becker, K. (2013). A respirometer system to measure critical and recovery oxygen tensions of fish under simulated diurnal fluctuations in dissolved oxygen. Aquaculture International, 21, 31-44.

Marshall, D.J., \& McQuaid, C.D. (2011). Warming reduces metabolic rate in marine snails: adaptation to fluctuating high temperatures challenges the metabolic theory of ecology. Proceedings of the Royal Society B, 278, 281-288.

Morgan, J.D., \& Iwama, G.K. (1991). Effects of salinity on growth, metabolism, and ion regulation in juvenile rainbow and steelhead trout (Oncorhynchus mykiss) and fall chinook salmon (Oncorhynchus tshawytscha). Journal of Fisheries and Aquatic Science, 48, 2083-2094.

Norin, T., \& Malte, H. (2011). Repeatability of standard metabolic rate, active metabolic rate and aerobic scope in young brown trout during a period of moderate food availability. Journal of Experimental Biology, 214, 1668-1675.

Norin, T., \& Clark, T.D. (2016). Measurement and relevance of maximum metabolic rate in fishes. Journal of Fish Biology, 88, 122-151.

Oh, S.Y., Noh, C.H., Kang, R.S., \& Myoung, J.G. (2006). Effect of water temperature and photoperiod on the oxygen consumption rate of fasted juvenile parrot fish, Oplegnathus fasciatus. Ocean and Polar Research, 28, 407-413.

Ohlberger, J., Staaks, G., \& Holker, F. (2007). Estimating the active metabolic rate (AMR) in fish based on tail beat frequency (TBF) and body mass. Journal of Experimental Zoology, 307, 296-300.
Prakoso, V.A., Kim, K.T., Min, B.H., Gustiano, R., \& Chang, Y.J. (2015). Effects of salinity on oxygen consumption and blood properties of young grey mullets M ugil cephalus. Indonesian Aquaculture Journal, 10(2), 143-153.

Prakoso, V.A., Ryu, J.H., Min, B.H., Gustiano, R., \& Chang, Y.J. (2016). Oxygen consumption of rockbream Oplegnathus fasciatus in different salinity levels and temperature degrees. Berita Biologi, 15(2), 167-173.

Requena, A., Fernandez-Borras, J., \& Planas, J. (1997). The effects of a temperature rise on oxygen consumption and energy budget in gilthead sea bream. Aquaculture International, 5, 415-426.

Reyes, A.B., Pendergast, J.S., \& Yamazaki, S. (2008). Mammalian peripheral circadian oscillators are temperature compensated. Journal of Biological Rhythms, 23, 95-98.

Rosewarne, P.J., Wilson, J.M., \& Svendsen, J.C. (2016). Measuring maximum and standard metabolic rates using intermittent-flow respirometry: a student laboratory investigation of aerobic metabolic scope and environmental hypoxia in aquatic breathers. Journal of Fish Biology, 88, 265-283.

Sarma, K., Pal, A.K., Ayyappan, S., Das, T., Manush, S.M., Debnath, D., \& Baruah, K. (2010). Acclimation of Anabas testudineus (Bloch) to three test temperatures influences thermal tolerance and oxygen consumption. Fish Physiology and Biochemistry, 36, 85-90.

Speakman, J.R. (1986). The optimum search speed of terrestrial predators when feeding on sedentary prey: a predictive model. Journal of Theoretical Biology, 122, 401-407.

Werner, E.E., \& Anholt, B.R. (1993). Ecological consequences of the trade off between growth and mortality rates mediated by foraging activity. American Naturalist, 142, 242-272.

White, C.R., Schimpf, N.G., \& Cassey, P. (2013). The repeatability of metabolic rate declines with time. Journal of Experimental Biology, 216, 1763-1765.

Yan, M.C., Shan, L.Z., Xie, Q.L., Lin, S.Z., Shao, X.B., Liu, W.C., \& Huang, X.K. (2008). Influence of temperature, salinity and body weight on oxygen consumption and ammonia excretion of Oplegnathus fasciatus juvenile. Advances in Marine Science, 26(4), 486-496. 